\title{
Feeding studies of radiation sterilization ready to eat foods on sprague dawley rats: In vivo
}

\author{
Zubaidah Irawati $^{{ }^{*}}$, Yulvian Sani ${ }^{2}$ \\ ${ }^{1}$ Centre for the Application of Isotopes and Radiation Technology, National Nuclear Energy Agency, Jakarta, Indonesia; \\ *Corresponding Author: irakoenari@yahoo.com \\ ${ }^{2}$ Indonesian Research Centre for Veterinary Science, Indonesian Agency for Agricultural Research and Development, Ministry of \\ Agriculture, Bogor, Indonesia
}

Received 15 November 2011; revised 22 December 2011; accepted 29 December 2011

\section{ABSTRACT}

Development of gamma irradiated high moisture traditional dishes derived from locally traditional récipe aimed for specific target groups as ready to eat foods for ensuring the safety, quality, and security purposes have been conducted. The formation of free radicals in the traditional foods induced by ionizing radiation is a part of toxicological studies on irradiated traditional foods was to provide local scientific data base on safety issues.The different foods such as steamed gold fish, spicy curry beef and soy sauces beef were individually vacuum packed in a laminate pouch of PET $12 \mu \mathrm{m} /$ LDPE $2 \mu \mathrm{m} /$ AL-Foil $7 \mu \mathrm{m} /$ LDPE 2 $\mu \mathrm{m} / L L D P E 50 \mu \mathrm{m}$ (PET/AI-Foil/LLDPE), then kept at frozen state. The frozen samples were maintained in cryogenic condition along the irradiation process by placing the samples in styrofoam boxes filled with dry ice then irradiated with gamma rays at the dose of $45 \mathrm{kGy}$. The irradiated samples were kept and stored at normal temperature prior to test. Both irradiated conventional rat's feed at normal temperature with the dose of $4 \mathrm{kGy}$ and unirradiated one as control were also made. Irradiated and unirradiated samples were sent to animal laboratory, and fed into individual female Sprague Dawley rat as member of a group. The parameters observed were body weight changed of rats, toxicological test to observe the effect free radicals formation in rat's blood by using malon-dialdehyde (MDA) and superoxide dismutase (SOD) methods, respectively, and anatomy pathology diagnosis. Different types of the foods sterilized by ionizing radiation fed ad libitum to the individual Sprague Dawley rat demonstrated that such foods did not give any adverse effect on the reduction of body weight, the toxicological impact, nor anatomypathology examinations of the rats.
Keywords: Ionizing Radiation; Ethnic Ready to Eat Food; Anatomy-Pathology; Toxicological Studies

\section{INTRODUCTION}

Food irradiation is an alternative technology using ionizing radiation for sanitization and preservation of food. The characterisitic of processing food by ionizing radiation is the high energy density per atomic transition. This could cleave molecules and induce ionization, which can not be achieved by heating process. The ionizing radiation treatment of solid food can provide simillar effects as heat pasteurization of liquids such as milk, however pasteurization and irradiation are different two processes [1-3].

The main target of using this technology is to destroy harmful microorganisms such as pathogenic bacteria, as well as parasites, and insects that may be present in the foodstuff as indigenous contamination. Furthermore the ionizing radiation could destroy the DNA molecules of the microorganisms and suppress proliferation of their pathogenic pathway which can give adverse effects to the products prior to consumption. Consequently, this may also prolong the shelf-life of the food since microbial spoilage is limiting without affecting the overall quality of the food. Some local foods such as herbs and spices that are irradiated at sufficient doses could reduce the microbial counts by several orders. These herbs when used as ingredients is expected not to carry over spoilage or pathogen microorganisms inside the final product.

Presently food safety is becoming a major issue in Indonesia, meaning the demand of consumers to get safe, healthy and better quality of food. Sustainability of good quality is expected to be provided when the local food materials is used for traditional dishes. Ready serving food of traditional dishes could be developed to be safe, nutritious, practical and a have longer shelf-life [4,5], and such foods are addressed to specific target groups such as hajj pilgrim, people who have outdoor activities and stay at 
remote area. Ready serving food can be served in a selected laminated-vacuum sterilized and preserved package [6]. This is done by non-thermal specific technology such as gamma irradiation starting from the minimum dose of about 10 - $45 \mathrm{kGy}$ [7]. Usually processed food products with high moisture content, when irradiate at high doses, should be combined with other processes such as using low temperature $\left(-79^{\circ} \mathrm{C}\right)$ and proper packaging materials during the irradiation process [8]. The gamma irradiation technique could inactivate pathogenic bacteria including spore bacteria resulting in better quality products without change of taste [9]. This technique can also produce long lasting product, with a shelf-life of about 1.5 years at room temperature $\left(28^{\circ} \mathrm{C} \pm 2^{\circ} \mathrm{C}\right) \quad[10]$. The economically feasibility of this technique is supported by the reducing production cost and dependency on cooling units during distribution and marketing [11].

The main problem of irradiation technology in food production is the safety of irradiated food as free radicals and their derivates may be detected and affect public health. Feeding studies of irradiated food in laboratory animals have been performed since 1950s [12,13]. The end point investigation included subchronic and chronic changes in metabolism, histopathology and function of most systems; reproductive effects; growth; teratogenicity; and mutagenicity. These studies have supported the safety of irradiated food [13-16]. Food safety of irradiated fresh food, dried food and processed food at the dose rate above 10 kGy had been intensively investigated by experts from some countries within a Joint FAO/IAEA/WHO Study Group on high-dose irradiation. The study concluded that high dose irradiation, above $10 \mathrm{kGy}$, on food materials were safe as with thermal sterilization process [17].

Monsen [18] reported that a lesion was found in left auricular appendage of heart in some mice of $\mathrm{Cb}$ and Strong A strains. Similar lesions were also reported by Fry et al. [19] and Meier and Hoag [20] to occur in old inactive breeders of the Balb/C strain mice. Furthermore, Thompson et al. [12] also reported that dilation and rupture of cardiac auricular were noted in mice of the $\mathrm{Cb}$ and Strong A strain fed on irradiated food. However, there are insufficient reports on toxicity effects of irradiated Indonesian traditional food available in Indonesia. The present study is therefore conducted to evaluate food safety of irradiated traditional foods served as ready to eat meals in adult female Sprague Dawley rats.

\section{MATERIALS AND METHODS}

\subsection{Preparation of Irradiated Food}

Foods were made according to the beef and fish based in Indonesian traditional dishes known as steamed gold fish (pepes ikan mas), spicy curry beef (rendang daging), and soy sauces beef (semur daging). The foods were individually packed in a laminate pouch of PET/ALFoil/LLDPE under vacuum condition, stored at $-18^{\circ} \mathrm{C}$ for $48 \mathrm{~h}$, then removed to styrofoam boxes filled with dry ice to maintain cryogenic state and irradiated with cobalt- 60 as a gamma source at the minimum dose of $45 \mathrm{kGy}$. The main target of this condition was to crystallize both bound and free water within the foods. The formation of most free radicals, in which can only perform in nano seconds, were suppressed by the frozen state and no longer exist nor attack the food compounds [13] while most pathogenic bacteria including spore formed bacteria were effectively killed by the high radiation dose.

Irradiation of the conventional feed at $4 \mathrm{kGy}$ was carried out as positive control and non-irradiated (0 kGy) conventional feed as negative control. Positive control samples were kept at room temperature while the negative control was kept in a refrigerator until used. Irradiation was carried out at the IRKA irradiator facility, located at Centre for the Application of Isotop and Radiation Technology, National Nuclear Energy Agency, Jakarta. Conventional feed, as a type of daily feeding given to the animals, was also prepared as comparative study. List of irradiated food and normal feed to feed the animals are shown in Table $\mathbf{1 .}$

\subsection{Experimental Design}

The in vivo toxicity study was carried out using 121 heads of adult female Sprague Dawley rats weighing from $100-150$ g. All rats were treated individually for each observation during the experiment. The rats were provided by the Laboratory Animal Breeding Unit of IRCVS Bogor Agricultural University, in Bogor. Female rats were selected due to the degree of sensitivity in their hormonal systems against free radicals. The animals were divided into 2 groups of 81 and 40 rats in each group and allowed for acclimatisation for one week prior to treatment. Group one was further subdivided into 18 subgroups of 5 rats each. Sixteen subgroups were fed with irradiated foods at $45 \mathrm{kGy}$ namely steamed gold fish, spicy curry beef and soy sauces beef of $75 \mathrm{~g} /$ day for 7 days, consecutively. The other 2 subgroups were allocated for control groups fed ad libitum (unlimited amount of food intake) on irradiated at $4 \mathrm{kGy}$ and non-irradiated of conventional feed each subgroups. The animals at the last feeding trials and 2 weeks after substitution of treated diet with conventional feeds were then terminated for necropsy and anatomy pathology examination. Group two of 40 rats was divided into 8 subgroups and fed ad libitum on irradiated foods, unirradiated foods, irradiated and control conventional feed for 7 days, respectively. Simillar procedure was also applied in this group. Tap water was provided ad libitum for their drinking water. 
Table 1. List of irradiated food and diet for the in vivo study in Sprague Dawley rats.

\begin{tabular}{|c|c|c|c|c|c|}
\hline No. & Types of food & Treatment & Date of irradiation & $\begin{array}{l}\text { Date of expire } \\
\text { (at room temperature) }\end{array}$ & $\begin{array}{l}\text { Total } \\
\text { numbers }\end{array}$ \\
\hline 1 & Steamed gold fish (pepes ikan mas) & Irradiated & $11 / 11 / 2006$ & $11 / 11 / 2007$ & 3 \\
\hline 2 & Steamed gold fish (pepes ikan mas) & Irradiated & 04/06/2007 & 04/06/2008 & 3 \\
\hline 3 & Steamed gold fish (pepes ikan mas) & Irradiated & 08/04/2008 & 08/04/2009 & 3 \\
\hline 4 & Steamed gold fish (pepes ikan mas) & Irradiated & $16 / 11 / 2008$ & $16 / 11 / 2009$ & 3 \\
\hline 5 & Steamed gold fish (pepes ikan mas) & Irradiated & $02 / 09 / 2009$ & $02 / 09 / 2010$ & 3 \\
\hline 6 & Steamed gold fish (pepes ikan mas) & Control & $16 / 11 / 2008$ & $19 / 11 / 2008$ & 3 \\
\hline 7 & Steamed gold fish (pepes ikan mas) & Control & 02/09/2009 & 05/09/2009 & 3 \\
\hline 8 & Spicy curry beef (rendang daging) & Irradiated & $04 / 06 / 2007$ & $04 / 06 / 2008$ & 3 \\
\hline 9 & Spicy curry beef (rendang daging) & Irradiated & $16 / 11 / 2008$ & $16 / 11 / 2009$ & 3 \\
\hline 10 & Spicy curry beef (rendang daging) & Irradiated & 02/09/2009 & $02 / 09 / 2010$ & 3 \\
\hline 11 & Spicy curry beef (rendang daging) & Control & $16 / 11 / 2008$ & $19 / 11 / 2008$ & 3 \\
\hline 12 & Spicy curry beef (rendang daging) & Control & $02 / 09 / 2009$ & 05/09/2009 & 3 \\
\hline 13 & Soy sauces beef (semur daging) & Irradiated & 08/04/2008 & 08/04/2009 & 3 \\
\hline 14 & Soy sauces beef (semur daging) & Irradiated & $16 / 11 / 2008$ & $16 / 11 / 2009$ & 3 \\
\hline 15 & Soy sauces beef (semur daging) & Irradiated & 02/09/2009 & $02 / 09 / 2010$ & 3 \\
\hline 16 & Soy sauces beef (semur daging) & Control & $16 / 11 / 2008$ & $19 / 11 / 2008$ & 3 \\
\hline 17 & Soy sauces beef (semur daging) & Control & $02 / 02 / 2009$ & 05/02/2009 & 3 \\
\hline 18 & Conventional feed (4 kGy) & Irradiated & $16 / 11 / 2008$ & $16 / 5 / 2009$ & 1 \\
\hline 19 & Conventional feed (4 kGy) & Irradiated & $02 / 09 / 2009$ & $02 / 03 / 2010$ & 1 \\
\hline 20 & Unirradiated conventional feed & Control & 02/09/2009 & $02 / 12 / 2009$ & 2 \\
\hline
\end{tabular}

Blood samples were collected from each rats for malondialdehyde (MDA) and superoxide dismutase (SOD) analysis. Part of livers and spleens were collected and kept in a freezer until used for MDA and SOD analysis. Gross pathology was observed and recorded for further analysis. While, another part of liver, kidneys, spleen, heart and lungs were collected and fixed in $10 \%$ buffered neutral formalin for histopathology examination.

\subsection{Anatomy Pathology Examination}

Rats were divided into two groups and fed on different irradiated foods consisted of irradiated steamed gold fish, spicy curry beef and soy sauces beef at 75 g per day for 7 days consecutively. The other two subgroups of animals were allocated as control groups fed on irradiated normal feed and non-irradiated normal feed, subsequently. The rats were weighed daily throughout feeding study to see the daily body weight gain. Clinical signs were observed and recorded everyday throughout the feeding study. Some rats of 9 subgroups were terminated for necropsy at the last day of feeding on irradiated food and the other 9 subgroups were necropsied 14 days after the substitution of treated food with conventional animal feed. Anatomy pathological changes were examined for each rat.

The experimental animals were provided by the Laboratory Animal Breeding Unit Indonesian Research Centre for Veterinary Science, Bogor consisting of 121 female rats of Sprague Dawley strain and weighing from 100 $150 \mathrm{~g}$. The rats were divided into 2 group of 81 and 40 rats each group and allowed for acclimatitation for one week prior to treatment. Group-1 was divided into 18 subgroups of 5 rats each. Sixteen groups were fed on irradiated food consisting steamed gold fish, spicy curry beef and soy sauces beef of 75 gram/day for 7 days consecutively. The other 2 groups were allocated for control groups fed ad libitum on irradiated feed and non-irradiated feed each subgroups. Group- 2 of 40 rats was divided into 8 subgroups and were fed ad libitum on irradiated food, control irradiated food and control diets for 7 days. Tap water was provided ad libitum for their drinking water. The animals were terminated at the last feeding trials and 2 weeks after substitution of treated diet with normal diets for necropsy examination.

\subsection{Malondialdehyde (MDA) and Superoxide Dismutase (SOD) Assays}

Blood samples were collected from each rats through cardiac puncture using an appropriate syringe. The animals were handled humanely following a standard procedure while collecting the blood samples. The bloods were collected in two different tubes such as heparinized tubes and plain tubes for SOD and MDA analysis subsequently. 


\subsubsection{Malondialdehyde Analysis}

The blood were centrifuged at 10,000 rpm for $10 \mathrm{~min}-$ utes. The plasma of $1 \mathrm{ml}$ were mixed with $1 \mathrm{ml} 0.9 \% \mathrm{NaCl}$ for 2 times. They were then centrifuged at 10,000 rpm for 10 minutes and filled out the filtrate. The supernatant was then mixed with $2 \mathrm{ml}$ aquadest and centrifuged at 10.000 rpm for 10 minutes. The filtrate was then collected for MDA analysis following Wills' method [21].

Plasma of $200 \mu \mathrm{l}$ was placed into a tube and added aquadest to $2 \mathrm{ml}$ volume, then mixed with $1 \mathrm{ml}$ trichloroacetic acid (TCA) $20 \%$ and $2 \mathrm{ml}$ thiobarbiturate acid (TBA) $0.67 \%$. The solution was then homogenized, warmed in boiled water for 10 minutes and allowed in room temperature. It was then centrifuged at $3.000 \mathrm{rpm}$ for $10 \mathrm{minu}-$ tes. The filtrate was collected for determining the concentration of MDA using a UV-VIS spectrophotometer at wavelength of $530 \mathrm{~nm}$. The concentration of MDA in plasma was calculated using a standard curve of MDA at concentration $0.0125 ; 0.025 ; 0.05 ; 0.1 ; 0.2 ; 0.4 ; 0.8$; and $1.6 \mathrm{nmol} / \mathrm{ml}$.

\subsubsection{Superoxide Dismutase Analysis}

SOD was determined from red blood cells following a method described by Misra and Fridovich [22]. Hemolisate of red blood cells $(250 \mu \mathrm{l})$ was extracted with $400 \mu \mathrm{l}$ $96 \%$ chloroform-ethanol mixture (3:5) for 1 minute followed by centrifugation at $3000 \mathrm{rpm}$ for 10 minutes. The filtrate of $10 \mu \mathrm{l}$ was mixed with $90 \mu \mathrm{l}$ aquadest, $2775 \mu \mathrm{l}$ buffer carbonate $0.0518 \mathrm{M}$ and $125 \mu \mathrm{l}$ epinephrine 0.025 $\mathrm{M}$. The mixtures were homogenized and filled into a cuvette for the determination of SOD in plasma using a spectrophotometer at $480 \mathrm{~nm}$ and $30^{\circ} \mathrm{C}$. The same procedure was also applied for a blank sample.

\section{RESULTS AND DISCUSSION}

\subsection{Average Changing in Body Weight and Clinical Studies}

The observation of female Sprague Dawley rats after feeding both on unirradiated and irradiated conventional feeds, and samples of ethnic ready to eat foods have been conducted based on the changes of body weight and pathological parameters. The results are illustrated in Figures 1 to 3, respectively. It is obvious from the figures that the average body weight of rats showed an increase after feeding of the irradiated ethnic foods.

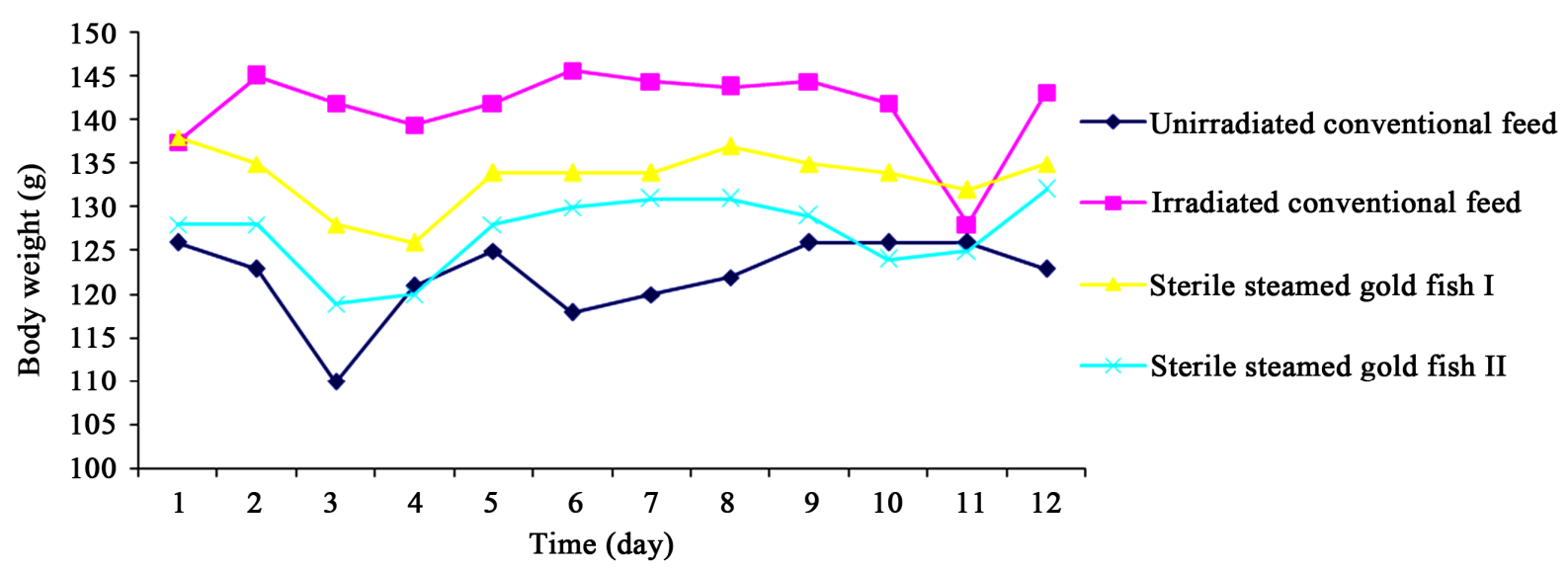

Figure 1. The average of body weight ( $\mathrm{g}$ ) of female Sprague Dawley rats before and after feeding unirradiated and irradiated steamed gold fish at $45 \mathrm{kGy}$.

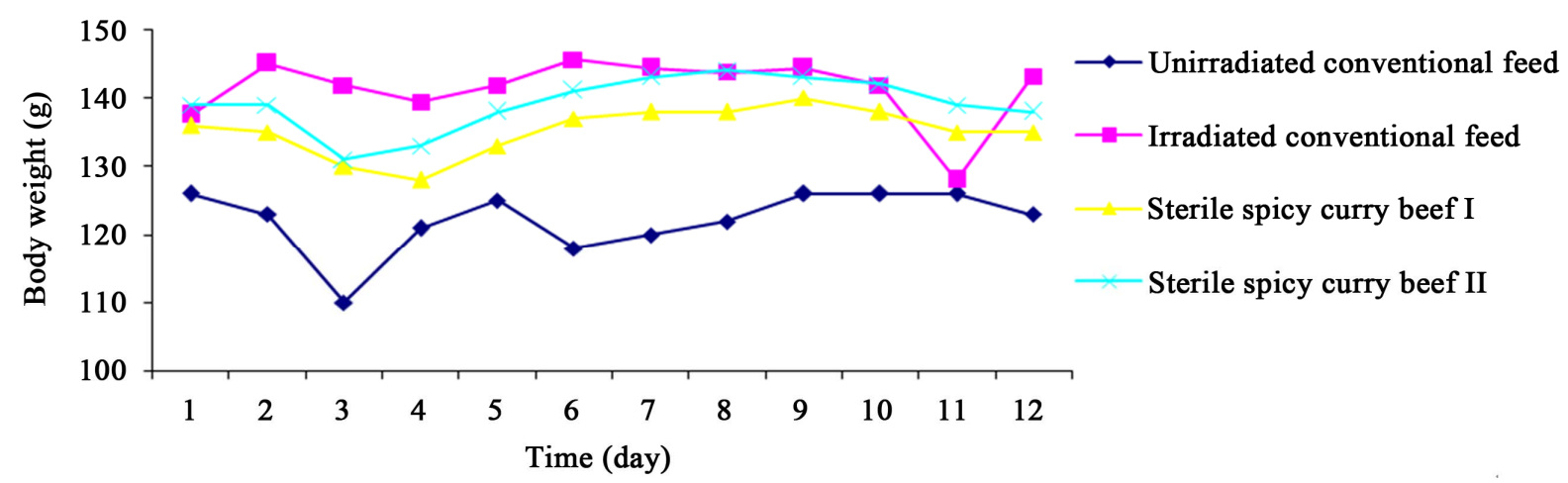

Figure 2. The average of body weight ( $\mathrm{g}$ ) of female Sprague Dawley rats before and after feeding unirradiated and irradiated spicy curry beef at $45 \mathrm{kGy}$. 


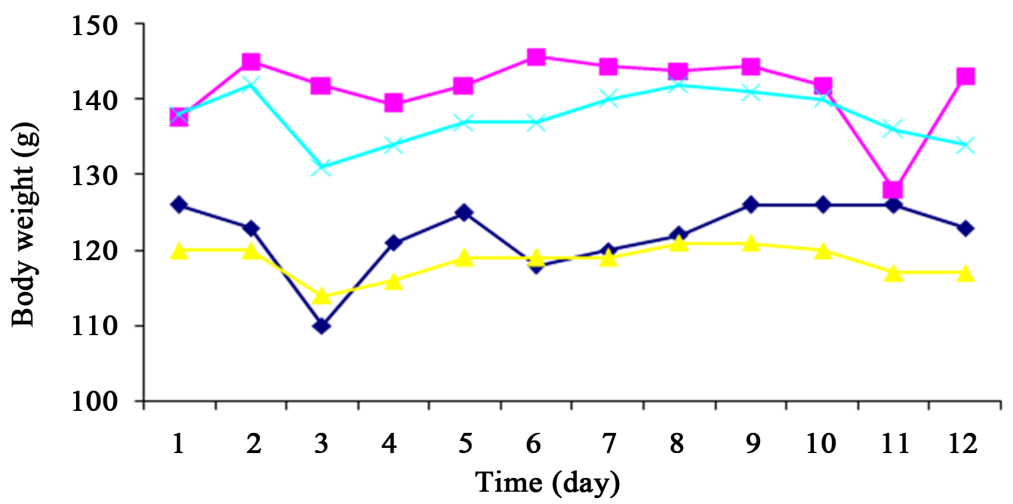

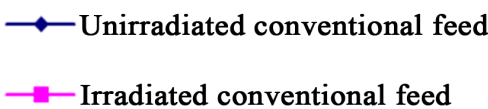

Sterile soy sauces beef I

Sterile soy sauces beef II

Figure 3. The average of body weight ( $\mathrm{g}$ ) of female Sprague Dawley rats before and after feeding unirradiated and irradiated soy sauces beef at $45 \mathrm{kGy}$.

Table 2. The $1^{\text {st }}$ day and the $21^{\text {st }}$ day after foods/feeds intervension for anatomy pathology diagnosis purpose.

\begin{tabular}{llll}
\hline No & Type of foods/feeds & $\begin{array}{l}\text { Anatomy-pathology diagnosis } \\
\text { The } 1^{\text {st }} \text { day after foods/feeds intervension }\end{array}$ & The $21^{\text {st }}$ day after foods/feeds intervension \\
\hline 1 & Unirradiated steamed gold fish & $\begin{array}{l}\text { Liver pale. } \\
\text { Hepatic necrosis and splenomegaly }\end{array}$ & $\begin{array}{l}\text { Mottling on the surface of liver. } \\
\text { No specific changes indicated to sick animal }\end{array}$ \\
2 & Irradiated steamed gold fish & $\begin{array}{l}\text { Splenomegaly and liver pale. } \\
\text { Liver degeneration }\end{array}$ & $\begin{array}{l}\text { Splenomegaly } \\
\text { General hyperemia }\end{array}$ \\
3 & Unirradiated spicy curry beef & $\begin{array}{l}\text { Splenomegaly } \\
\text { No specific changes indicated to sick animal. }\end{array}$ & Splenomegaly \\
4 & Irradiated spicy curry beef & $\begin{array}{l}\text { Splenomegaly and mottling on the surface of liver } \\
\text { Liver degeneration }\end{array}$ & $\begin{array}{l}\text { No specific changes indicated to sick animal } \\
\text { Hepatic nodular and splenomegaly }\end{array}$ \\
5 & Unirradiated soy sauces beef & $\begin{array}{l}\text { Mottling on the surface of liver and emphysema } \\
\text { Liver degeneration }\end{array}$ & $\begin{array}{l}\text { Splenomegaly } \\
\text { No specific changes indicated to sick animal }\end{array}$ \\
6 & Irradiated soy sauces beef & $\begin{array}{l}\text { Mottling on the surface of liver and emphysema } \\
\text { Liver degeneration }\end{array}$ & $\begin{array}{l}\text { Splenomegaly } \\
\text { No specific changes indicated to sick animal }\end{array}$ \\
7 & Unirradiated conventional feed & No specific changes indicated to sick animal & No specific changes indicated to sick animal \\
8 & Irradiated conventional feed & $\begin{array}{l}\text { Splenomegaly } \\
\text { No specific changes indicated to sick animal }\end{array}$ & No specific changes indicated to sick animal
\end{tabular}

Table 3. Results of MDA assay $(\mathrm{nmol} / \mathrm{ml})$ in blood plasma of Sprague Dawley after intervention of ready to eat foods and conventional feeds.

\begin{tabular}{llcc}
\hline \multirow{2}{*}{ No } & Type of foods/feeds & \multicolumn{2}{c}{ Days } \\
& & $7^{\text {th }}$ & $15^{\text {th }}$ \\
\hline 1 & Unirradiated steamed gold fish & 0.090 & 0.317 \\
2 & Irradiated steamed gold fish & 0.097 & 0.068 \\
3 & Unirradiated spicy curry beef & 0.241 & 0.569 \\
4 & Irradiated spicy curry beef & 0.434 & 0.355 \\
5 & Unirradiated soy sauces beef & 0.105 & 0.210 \\
6 & Irradiated soy sauces beef & 0.083 & 0.383 \\
7 & Unirradiated conventional feed & 0.103 & 0.117 \\
8 & Irradiated conventional feed & 0.250 & 0.354 \\
\hline
\end{tabular}

Clinical symptom of Sprague Dawley were not detected neither before nor after feeding the animal with irradiated foods. After feeding, the animals seemed to be healthy and have better movement and no leftover of food found in the cage. The fur was more glittering, clean and no death animals were found after treatment.

\subsection{Anatomy Pathology}

Results of visual analysis from different food treatments are presented in Table 2.

\subsection{Malondialdehyde (MDA) and Superoxide Dismutase (SOD) Assays}

Table 3 shows the results of MDA content in blood plasma of Sprague Dawley after intervention with some ethnic ready to eat foods and conventional feeds, respecttively. It showed that immediately after treatment, ioniz- 
ing radiation at the dose of $45 \mathrm{kGy}$ of spicy curry beef and irradiated conventional feeds at $4 \mathrm{kGy}$ could increase MDA content of blood plasma, while irradiated steamed for gold fish it did not affect the MDA content. Treatment at day- $15^{\text {th }}$ showed that MDA content in blood plasma was reduced significantly after intervention of irradiated steamed gold fish and spicy curry beef, respectively to the rats, but slight increased after feeding the rats with irradiated soy sauces beef and conventional feed.

Results of Superoxide Dismutase (SOD) in blood plasma $((\mathrm{U} / \mathrm{ml})$ is presented in Table 4. Superoxide dismutase (SOD) is an enzyme. SOD revitalizes cells and reduces the rate of cell destruction and neutralizes superoxide free radicals [23]. The results showed that the SOD values had significant increase in unirradiated and irradiated steam gold fish, but decreased in unirradiated and irradiated spicy curry beef and soy sauce beef at the $15^{\text {th }}$ day, respectively.

Ionizing radiation could reduce the SOD value in all samples either at the $7^{\text {th }}$ day or at the $15^{\text {th }}$ day, except in irradiated conventional feed after the $15^{\text {th }}$ day.

\section{CONCLUSION AND RECOMMENDATION}

It can be concluded from the obtained results that feeding studies of gamma irradiated at $45 \mathrm{kGy}$ in combination with irradiation condition and packaging method of steamed gold fish, spicy curry beef, and soy sauces beef on female Sprague Dawley rats, respectively did not show clinical symptoms nor anatomy pathology diagnosis of the observed rats in comparison to the unirradiated foods. Similar results was obtained from the conventional feed irradiated at $4 \mathrm{kGy}$. Irradiation at sterilization dose of high moisture and complex food matrix as well as traditional ready to eat foods should be properly vacuum packed in selected packaging material and irradiated under cryogenic condition to ensure the safety, quality, and security of the foods.

Table 4. Results of Superoxide Dismutase (SOD) assay in blood plasma $((\mathrm{U} / \mathrm{ml})$ of Spargue Dawley after intervention of ready to eat foods and conventional feeds.

\begin{tabular}{clcc}
\hline \multirow{2}{*}{ No } & Type of foods/ feeds & \multicolumn{2}{c}{ Days } \\
& & $7^{\text {th }}$ & $15^{\text {th }}$ \\
\hline 1 & Unirradiated steamed gold fish & 43.75 & 78.04 \\
2 & Irradiated steamed gold fish & 37.50 & 51.53 \\
3 & Unirradiated spicy curry beef & 82.86 & 79.93 \\
4 & Irradiated spicy curry beef & 53.21 & 46.52 \\
5 & Unirradiated spicy curry beef & 88.37 & 61.38 \\
6 & Irradiated soy sauces beef & 71.87 & 54.75 \\
7 & Unirradiated conventional feed & 68.19 & 50.00 \\
8 & Irradiated conventional feed & 44.88 & 72.22 \\
\hline
\end{tabular}

\section{ACKNOWLEDGEMENTS}

The authors wish to thank to National Nuclear Energy Agency for financial support, and to the Research Institute for Veterinary Science, Bogor for providing the laboratory facility to conduct the work. Special thanks are also addressed to colleagues at the agency and institute for their sincere assistances.

\section{REFERENCES}

[1] Wood, A.B. and Bruhn, C.M. (2000) Position of the American Dietetic Association: Food irradiation. Journal of the American Dietetic Association, 100, 246-253. doi:10.1016/S0002-8223(00)00075-4

[2] Deeley, C.M., Gao, M., Hunter, R. and Ehlermann, D.A.E. (2006) The development of food irradiation to-date in the Asia Pacific, the Americas, Europe and Africa. The 14th International Meeting on Radiation Processing, IMRP, Kuala Lumpur, Malaysia, 26 February-3 March 2006.

[3] Kume, T., Furuta, M., Todoriki, S., Uenoyama, N. and Kobayashi, Y. (2009) Status of food irradiation in the world. Radiation Physics and Chemistry, 78, 222-226. doi:10.1016/j.radphyschem.2008.09.009

[4] Langseth, L. (2000) Antioxidants and their effect on health. In: Schidl, M.K. and Labiza, T.P. Eds., Essentials of Functional Food, USA Aspen Publisher Inc, Maryland, 303-317.

[5] Zakaria-Rungkat, F. (2001) Effectiveness of traditional foods as functional foods and supplements. In: Dewanti, R. and Nuraida, L. Eds., Traditional Foods a Base of Functional Food and Supplements, PKMT Institut Pertanian Bogor, Bogor.

[6] Haruvy, Y. and Deschenes, L. (2003) Packaging quality assurance guidance manual model for safe, shelf-stable, ready-to-eat food through high-dose irradiation. Radiation Processing for Safe, Shelf-Stable and Ready to Eat Food, Proceedings of a Final Research Co-ordination Meeting, Montreal, 10-14 July 2000, IAEA-TECDOC1337, International Atomic Energy Agency (IAEA), Vienna, Austria, 238-257.

[7] Anonymous (2002) Dosimetry for food irradiation. IAEA Technical Report Series No. 409, IAEA, Vienna.

[8] Anonymous (1995) Shelf-stable foods through irradiation processing. IAEA-TECDOC-843, Report prepared by the Food Preservation Section, Joint FAO/IAEA Division of Nuclear Techniques in Food and Agriculture, IAEA, Vienna.

[9] Irawati, Z., Natalia, L., Ansori, N., Nurcahya, C.M., Anas, F. and Syafarudin, M. (2003) Innoculation packed studies on the shelf-stable food products: I. Effects of gamma irradiation at $45 \mathrm{kGy}$ on the survival of Clostridium sporongenes spores in the foods (preliminary results). Radiation Processing for Safe, Shelf-Stable and Ready to Eat Food, Proceedings of a Final Research CoOrdination Meeting, Montreal, 10-14 July 2000, IAEATECDOC-1337, International Atomic Energy Agency (IAEA), Vienna, 100-115.

[10] Irawati, Z., Maha, M., Ansori, N., Nurcahya, C.M. and 
Anas, F. (2003) Development of shelf-stable foods fish pepes, chicken and meat dishes through radiation processing. Radiation Processing for Safe, Shelf-Stable and Ready to Eat Food, Proceedings of a Final Research Co-Ordination Meeting, Montreal, 10-14 July 2000, IAEA-TECDOC-1337, International Atomic Energy Agency (IAEA), Vienna, 85-99

[11] DeBruyn, I.N. (2003) Commercial application of highdose irradiation to produce shelf-stable meat products, Part 2. Practical aspects of maintaining product at temperatures of between $-20^{\circ} \mathrm{C}$ and $-40^{\circ} \mathrm{C}$ during large scale irradiation. Radiation Processing for Safe, ShelfStable and Ready to Eat Food, Proceedings of a Final Research Co-Ordination Meeting, Montreal, 10-14 July 2000, IAEA-TECDOC-1337, International Atomic Energy Agency (IAEA), Vienna, 124-131.

[12] Thompson, S.W., Hunt, R.D., Ferrell, J., Jenkins, E.D. and Monsen, H. (1965) Histopathology of mice fed irradiated foods. Journal of Nutrition, 87, 274-284.

[13] Diehl, J.F. (1995) Safety of irradiated food. 2nd Edition, Marcel Dekker, New York.

[14] World Health Organization (1994) Safety and nutritional adequacy of irradiated food. World Health Organization, Geneva, Switzerland.

[15] US Department of Health and Human Services (1986) Irradiation in the production, processing and handling of food. Federal Register, 51, 13376-13399.

[16] World Health Organization (1999) High-dose irradiation:
Wholesomeness of food irradiated with doses above 10 kGy. Report of a Joint FAO/IAEA/WHO Study Group, WHO Technical Report Series No. 890, Geneva.

[17] Anonymous (1999) High dose irradiation: Wholesomeness of food irradiated with doses above $10 \mathrm{kGy}$. Report of a Joint FAO/IAEA/WHO Study Group, WHO Technical Report Series No. 890, Geneva.

[18] Monsen, H. (1960) Heart lesions in mice induced by feeding irradiated foods. Federation Proceedings, 19 1031-1034.

[19] Fry, J.M., Hamilton, K. and Lisco, H. (1960) An unusual spontaneous cardiac lesion of unknown etiology in mice. Federation Proceedings, 19, 109.

[20] Meier, H. and Hoag, W.G. (1961) Studies on left auricular thrombosis in mice. Experimental Medicine and Surgery, 19, 317 .

[21] Greenwald, R.A. (1985) CRC handbook of methods for oxygen radical research. CRC Press Inc., New York, 203-279.

[22] Misra, H.P. and Fridovich, I. (1972) The role of superoxide dismutase anion in the auto-oxidation of epinephrine and a simple assay for superoxide dismutase. Journal of Biochemistry, 247, 3170-3175.

[23] Balch, J.F. and Balch, P.A. (1997) Prescription for nutritional healing. 2nd Edition, Avery Publishing Group, New York. 